\title{
43. THE INFLUENCE OF BIOGENIC SILICA ON THE GEOTECHNICAL STRATIGRAPHY OF THE VØRING PLATEAU, NORWEGIAN SEA ${ }^{1}$
}

\author{
Alan Pittenger, ${ }^{2}$ Elliott Taylor, ${ }^{3}$ and William R. Bryant ${ }^{2}$
}

\begin{abstract}
Sediment composition and rate of deposition are the primary factors responsible for determining the spatial distribution of geotechnical properties on the Vøring Plateau. Grain size and depth of burial have no significant influence. Vertical and lateral changes in geotechnical properties are associated with vertical and lateral composition changes in which biogenic silica is the most important variable. Anomalous trends of decreasing density and increasing porosity and water content with depth are associated with increasing silica content downsection. Void ratios, inferred in-situ permeability, and change in void ratio during consolidation testing are relatively high in siliceous sediments and tend to increase as the biogenic silica content increases. Portions of the section are overconsolidated, probably as a result of changes in sediment accumulation rates. However, the higher permeabilities of siliceous sediments may also be a factor influencing consolidation state.
\end{abstract}

\section{INTRODUCTION}

The Ocean Drilling Program Leg 104 on the Vøring Plateau, Norwegian Sea (Fig. 1), obtained an extensive suite of geotechnical data onboard ship including measurements of bulk density, porosity, specific gravity, water content, thermal conductivity, shear strength, compressional wave velocity, and acoustic impedance (Eldholm, Thiede, Taylor, et al., 1987). Taylor (1984) demonstrated the usefulness of geotechnical properties in stratigraphic analysis. Depth profiles of Leg 104 geotechnical data were found to be very good stratigraphic tools for establishing correlations between physical properties and lithologic changes, for site to site correlation, and for correlation with seismic reflection horizons. The objective of the present study is twofold: to expand the shipboard data base to include consolidation and permeability test results, and also to evaluate the most significant factors controlling the range and distribution of geotechnical properties on the Vøring Plateau.

\section{METHODS}

Sediment composition was determined onboard ship from smear slides and carbonate bomb analysis. A description of shipboard laboratory techniques and procedures may be found in Eldholm, Thiede, Taylor, et al., (1987). Shore-based procedures included determination of Atterberg limits and indices, grain-size analysis, specific gravity, bulk density, water content, porosity, and consolidation properties.

Whole round, $10-\mathrm{cm}$ long samples selected on the ship were kept sealed and refrigerated prior to testing. All samples were recovered by advanced piston coring with the exception of two, 104-642B-23X-4 and 104-643A-18X-2 (Tables 1 and 2), which were retrieved by extended core barrel. Sediment samples were extruded from the core liner with as little disturbance as possible. A vane-shear measurement was taken within 1 to $2 \mathrm{~cm}$ of the interval selected for testing. Additional material in the immediate vicinity of the consolidation sample was collected for determination of salt-corrected water content (average of two samples), grain size, Atterberg limits, and pycnometer analysis.

Undrained vane-shear strength was measured using a Wykeham Farrance motorized device calibrated for a vane blade with height and diameter equal to $1.27 \mathrm{~cm}$. The vane was inserted perpendicular to bed-

\footnotetext{
${ }^{1}$ Eldholm, O., Thiede, J., Taylor, E., et al., 1989. Proc. ODP, Sci. Results, 104: College Station, TX (Ocean Drilling Program).

2 Dept. of Oceanography, Texas A\&M University, College Station, TX 77843.

3 Ocean Drilling Program, Texas A\&M University, 1000 Discovery Drive, College Station, TX 77840. Now at School of Oceanography, University of Washington, Seattle, WA 98195.
}

ding and rotated at $2.5 \mathrm{rpm}$. Standard techniques for sieve and pipet (Folk, 1974) were used for grain-size analysis. Samples were classified on the basis of grain size as muds, clays or silts (Folk, 1974). Procedures for determining liquid limits $\left(W_{l}\right)$ and plastic limits $\left(W_{p}\right)$ are specified and discussed by Lambe (1951). The plasticity index $\left(P_{I}\right)$ is calculated as $W_{l}-W_{p}$. The observed liquidity index $\left(L_{l}\right)$ is a relationship between the natural water content $\left(W_{n}\right)$ and the Atterberg limit and is defined as:

$$
L_{I}=\left(W_{n}-W_{p}\right) /\left(W_{1}-W_{p}\right)
$$

where $W_{n}=$ weight of water divided by the weight of the solids (corrected for salt content). Predicted liquidity index $\left(L_{I n}\right)$ was defined by McClelland (1967) as:

$$
\begin{aligned}
L_{l n}= & \left(100 e /\left(0.000722 W_{l}+2.667\right)\right)-\left(\left(W_{l}-0.831 W_{l}+14\right) /\right. \\
& \left.\left(0.831 W_{l}-14\right)\right)
\end{aligned}
$$

where $e$ is the predicted void ratio at the depth $(z)$ of the sample and is equal to:

$$
\begin{aligned}
e= & {\left[\log \left(P^{\prime}{ }_{z} / 95.76052\right)-\log 2\right] \times\left[0.011\left(W_{l}-16\right)\right] } \\
& +0.014\left(W_{l}+12.8\right) .
\end{aligned}
$$

Void ratio is defined as the volume of the voids divided by the volume of the solids. $P^{\prime}{ }_{z}$ is the effective overburden pressure at the sample depth.

Bulk density, specific gravity and porosity were determined using wet sediment weights and a Beckman model 930 pycnometer operated with helium gas to purge samples.

A total of 19 consolidation tests were completed on samples from the three sites drilled on Leg 104. X-radiographs of the samples, in their liners, were used to pick specific sample locations of minimum disturbance. Consolidation samples were taken from the center of cores to avoid core penetration disturbance near the core liner. Six of the tests were performed using a Geotechnical Digital Systems, Ltd. (GDS) consolidation testing system. These tests were run at a constant hydraulic gradient of $0.75 \%$ at $500 \mathrm{kPa}$ back pressure. Loads were incremented to $1970 \mathrm{kPa}$. The remaining 13 tests were performed using Anteus consolidometers at $689 \mathrm{kPa}$ back pressure with step loading to $3200 \mathrm{kPa}$. Consolidation testing of marine sediments by this latter method has been described in detail by Shephard et al. (1979) and Bryant et al. (1981).

The cumulative results of successively applied loads are plotted as the change in void ratio $(e)$ vs. the $\log$ of effective stress $\left(e-\log P^{\prime}\right.$ curves). The initial void ratio $\left(e_{o}\right)$ is calculated as:

$$
e_{o}=\left(A\left(2 H_{o}-H_{s}\right) / A H_{s},\right.
$$

where $A$ is the sample area of the sample, $H_{o}$ is the drainage height and $H_{s}$ is the height of the solids. $H_{s}=W_{s} /\left(A G_{s} W_{w}\right)$, where $W_{s}$ is the 


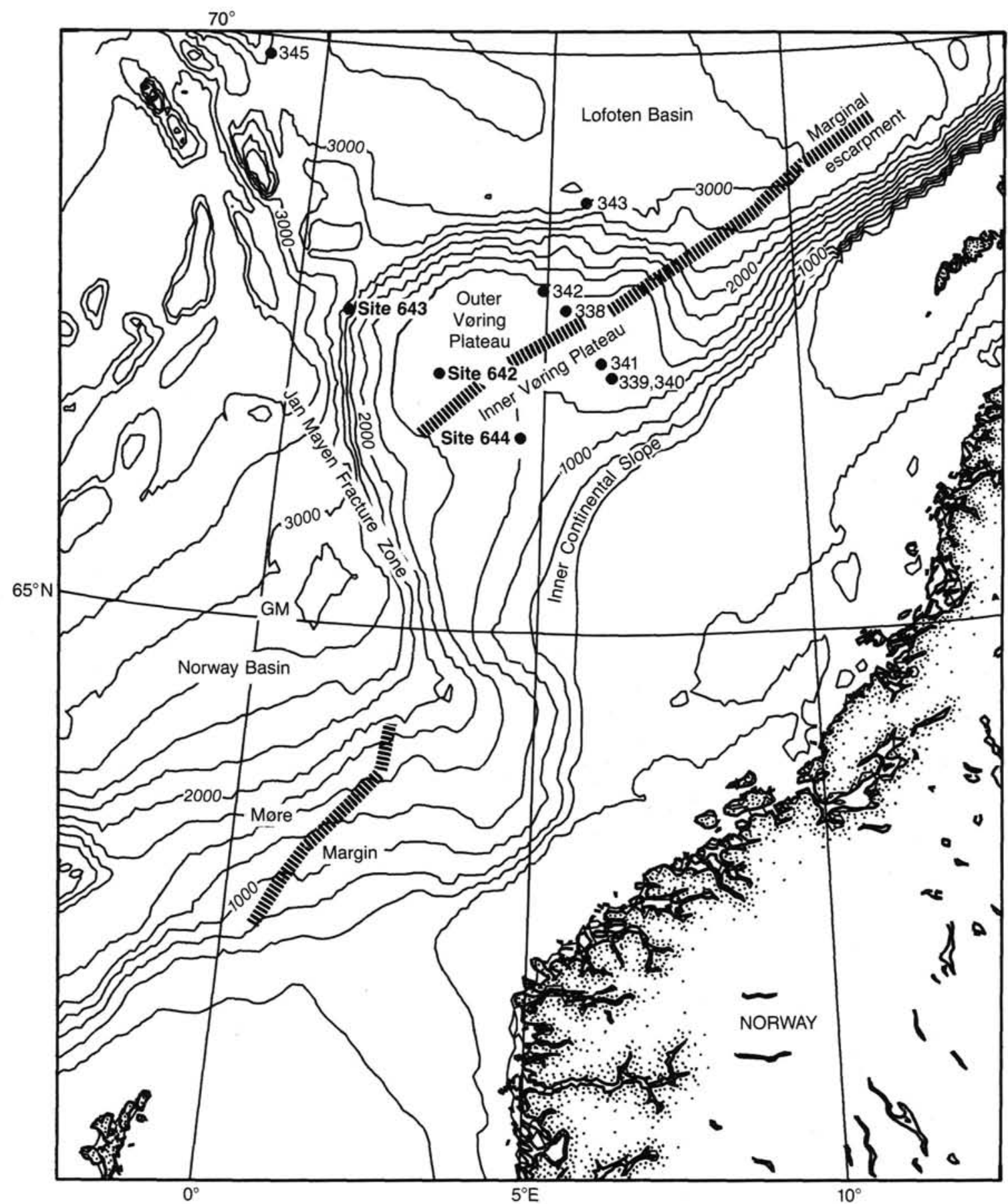

Figure 1. Drilling locations, Ocean Drilling Program Leg 104, Sites 642-644, Norwegian Sea. Contours in meters.

weight of the solids, $G_{s}$ is the specific gravity and $W_{w}$ is the unit weight of sea water $\left(1.025 \mathrm{~g} / \mathrm{cm}^{3}\right)$.

The compression index $\left(C_{c}\right)$ is determined from the maximum slope of the $e-\log P^{\prime}$ curve for each sample. This index is calculated as:

$$
C_{c}=\Delta e / \Delta \log P
$$

where the numerator is the change in void ratio associated with the change in loading pressure represented by the denominator.

The effective overburden pressure $\left(P_{o}{ }^{\prime}\right)$ is calculated from the equation derived by Helwick (1977):

$$
P_{\mathrm{o}}^{\prime}=9.8065[z(P B)-z(1025)]
$$

for a single interval where $z$ is the thickness of the interval, $P B$ is the wet bulk density, and $1025 \mathrm{~kg} / \mathrm{m}^{3}$ is the unit weight of seawater. Total effective overburden pressure is $P_{o}^{\prime}$ summed for each overlying interval.

The preconsolidation pressure $\left(P_{c}{ }^{\prime}\right)$, determined from the $e$-log $P^{\prime}$ curve using the technique of Casagrande (1936), is the maximum in-situ loading pressure the sample has experienced. The overconsolidation ratio $(\mathrm{OCR})$ is the ratio $P^{\prime} d P_{o}{ }^{\prime}$. An OCR greater than one indicates an overconsolidated state while an $\mathrm{OCR}$ of less than one indicates underconsolidation. The observed and predicted liquidity indices have also been used to indicate consolidation state where an $L_{I}$ greater than $L_{I n}$ indicates underconsolidation (McClelland, 1967; Helwick, 1977). 
Permeability was measured by falling-head tests after each load increment during the consoliation test. The coefficient of permeability $(k)$ was computed from the equation

$$
k(\mathrm{~cm} / \mathrm{sec})=(2.3026 a \mathrm{~L} / A t) \times \log \left(H_{o} / H_{i}\right),
$$

where $a$ is the cross-sectional area of the standpipe, $A$ is the cross-sectional area of the sample, $L$ is the flow path length or sample thickness, $t$ is the time, $H_{o}$ equals the original head, and $H_{i}$, the final head (Lambe, 1951). $k$ was also calculated from consolidation test results according to the equation

$$
k=C_{\nu} W_{w} M_{v},
$$

where $C_{v}$ is the coefficient of consolidation, $W_{w}$ is the unit weight of water, and $M_{v}$ is the coefficient of volume change. Methods of determining $C_{y}, M_{v}$, and $k$ by this method are discussed in Lambe (1951). The coefficient of permeability at the preconsolidation pressure $\left(k_{c}\right)$ is assumed to be equal to the in-situ value. Values of $k_{c}$ were found by interpolation from both measured and calculated values of $k$ for all load increments during consolidation tests. Measured and calculated permeabilities reported for GDS samples were determined from duplicate samples, taken within a few centimeters of the originals, and tested on Anteus consolidometers. Permeability testing was not available in conjunction with GDS test equipment.

\section{GEOTECHNICAL PROPERTIES}

The three locations drilled on ODP Leg 104 form a transect across the Vøring Plateau that lies perpendicular to the Norwegian coastline (Fig. 1). The drill sites are discussed in order of increasing distance from the coast.

\section{Site 644}

Seven samples were tested from Site 644, ranging in depth from 14 to 182 mbsf (meters below seafloor). These samples are classified by grain size as muds and clays (Table 1). All of the samples are composed of predominantly terrigenous material with relatively small amounts of carbonate and biogenic silica (Fig. 2).
Geotechnical properties at this site show only minor variations with depth, reflecting small changes in grain size and composition. Bulk density is inversely correlated with porosity and natural water content as expected (Fig. 2). Plastic limits and water contents also show little variation with depth; however, liquid limits gradually increase with depth. The increase in the plasticity index $\left(P_{I}\right)$ appears to be associated with the presence of biogenic silica in the section beginning at about $75 \mathrm{mbsf}$ (Fig. 2).

Void ratio vs. $\log$ effective stress $\left(e-\log P^{\prime}\right)$ curves for Site 644 samples are presented in Figure 3. All samples have curves that exhibit comparable, and relatively low, initial void ratios and show small changes in void ratio in response to vertical loading. This is probably a result of the relatively high coarse clastic content (sand and silt) present throughout the section at Site 644.

The compression index is another measure of sediment response to vertical loading: larger values of $C_{c}$ indicate a greater reduction in void ratio for a given increment of vertical load. Compression indices for the Site 644 samples vary only slightly (Table 2). The similarities in the $e-\log P^{\prime}$ curves and small variation in compression index are a further reflection of the relatively homogeneous geotechnical character of sediments at Site 644.

Calculated values of permeability are in the range of $10^{-7}$ to $10^{-9} \mathrm{~cm} / \mathrm{s}$ (Fig. 4) and differ significantly from the results of falling head tests: $10^{-4} \mathrm{~cm} / \mathrm{s}$. The calculated values are more typical of muds and clays and calculated values of $k$ are generally more reliable than falling head-measured values for low permeability sediments (Bryant et al., 1981). Estimated in-situ k shows an abrupt increase downsection, associated with the increasing abundance of biogenic silica (Fig. 4).

Overconsolidation ratios (Table 2) and a plot of effective overburden and preconsolidation pressures vs. depth (Fig. 5) indicate that sediments are underconsolidated to at least $182 \mathrm{mbsf}$ (OCR less than one and $P_{c}{ }^{\prime}$ vs. depth less than $P_{o}{ }^{\prime}$ vs. depth). However, from about 75 to 125 mbsf the degree of underconso-

\begin{tabular}{|c|c|c|c|c|c|c|c|c|c|c|c|c|c|}
\hline \multirow{2}{*}{$\begin{array}{l}\text { Core- } \\
\text { Section }\end{array}$} & \multirow{2}{*}{$\begin{array}{l}\text { Depth } \\
\text { (mbsf) }\end{array}$} & \multicolumn{3}{|c|}{ Grain size $(\%)$} & \multirow[b]{2}{*}{ Class. } & \multicolumn{3}{|c|}{$\begin{array}{c}\text { Atterberg } \\
\text { limits }\end{array}$} & \multirow{2}{*}{$\begin{array}{c}\text { Bulk } \\
\text { density } \\
\left(\mathrm{gm} / \mathrm{cm}^{3}\right)\end{array}$} & \multirow{2}{*}{$\begin{array}{c}\text { Specific } \\
\text { gravity }\end{array}$} & \multirow{2}{*}{$\begin{array}{c}\text { Water } \\
\text { content } \\
(\%)\end{array}$} & \multirow{2}{*}{$\begin{array}{c}\text { Porosity } \\
(\%)\end{array}$} & \multirow{2}{*}{$\begin{array}{c}\text { Shear } \\
\text { strength } \\
\text { (kPa) }\end{array}$} \\
\hline & & sand & silt & clay & & $W_{l}$ & $W_{p}$ & $P_{I}$ & & & & & \\
\hline \multicolumn{14}{|l|}{ Site 642} \\
\hline $2-5$ & 12.2 & 6 & 26 & 68 & Clay & 68 & 26 & 42 & 1.72 & 2.72 & 59 & 59 & 6.7 \\
\hline $5-4$ & 35.3 & 4 & 28 & 68 & Clay & 66 & 24 & 42 & 1.82 & 2.65 & 49 & 53 & 30.6 \\
\hline $8-4$ & 62.3 & 4 & 30 & 66 & Clay & 112 & 32 & 80 & 1.77 & 2.81 & 57 & 59 & 82.4 \\
\hline $11-4$ & 91.3 & 2 & 55 & 43 & Mud & 170 & 65 & 105 & 1.51 & 2.77 & 103 & 73 & 71.7 \\
\hline $17-3$ & 142.4 & 1 & 33 & 66 & Clay & 160 & 79 & 81 & 1.45 & 2.78 & 116 & 76 & 92.4 \\
\hline $20-5$ & 174.8 & 2 & 33 & 65 & Mud & 204 & 97 & 107 & 1.42 & 2.41 & 128 & 74 & 90.5 \\
\hline $23-4$ & 200.0 & 1 & 32 & 67 & Clay & 193 & 103 & 90 & 1.38 & 2.44 & 130 & 76 & 119.7 \\
\hline \multicolumn{14}{|l|}{ Site 643} \\
\hline $2-4$ & 11.2 & 17 & 38 & 45 & $\begin{array}{l}\text { Sandy } \\
\text { Mud }\end{array}$ & 49 & 20 & 29 & 1.89 & 2.74 & 43 & 51 & 12.9 \\
\hline $5-5$ & 41.2 & 5 & 31 & 64 & Clay & 115 & 34 & 81 & 1.72 & 2.85 & 62 & 63 & 37.3 \\
\hline $8-5$ & 69.7 & 1 & 94 & 5 & Silt & 211 & 94 & 117 & 1.40 & 2.96 & 158 & 81 & 89.0 \\
\hline $11-5$ & 97.9 & 7 & 59 & 34 & Mud & 255 & 71 & 184 & 1.47 & 2.64 & 140 & 75 & 48.4 \\
\hline $14-5$ & 126.7 & 3 & 59 & 38 & Silt & 220 & 101 & 119 & 1.42 & 2.42 & 154 & 76 & 82.4 \\
\hline $18-2$ & 160.2 & 3 & 51 & 46 & Mud & 237 & 95 & 142 & 1.37 & 2.60 & 158 & 80 & 19.6 \\
\hline \multicolumn{14}{|l|}{ Site 644} \\
\hline $2-3$ & 13.6 & 9 & 30 & 61 & Clay & 58 & 21 & 37 & 1.82 & 2.82 & 55 & 56 & 50.0 \\
\hline $5-2$ & 38.1 & 6 & 28 & 66 & Clay & 72 & 27 & 45 & 1.82 & 2.79 & 53 & 57 & 7.8 \\
\hline $9-4$ & 78.9 & 0 & 33 & 67 & Mud & 84 & 27 & 57 & 1.90 & 2.67 & 49 & 51 & 65.0 \\
\hline $11-5$ & 99.6 & 2 & 47 & 51 & Mud & 102 & 32 & 69 & 1.72 & 2.77 & 62 & 61 & 86.0 \\
\hline $14-3$ & 125.0 & 1 & 29 & 70 & Clay & 105 & 37 & 68 & 1.84 & 2.76 & 49 & 54 & 115.0 \\
\hline $17-2$ & 152.1 & 1 & 43 & 56 & Mud & 89 & 35 & 55 & 1.74 & 2.78 & 59 & 60 & 86.0 \\
\hline $20-3$ & 182.1 & 5 & 49 & 46 & Mud & 86 & 33 & 53 & 1.80 & 2.84 & 51 & 58 & 125.0 \\
\hline
\end{tabular}

Table 1. Physical properties of Norwegian Sea sediments. 
A. PITTENGER, E. TAYLOR, W. BRYANT

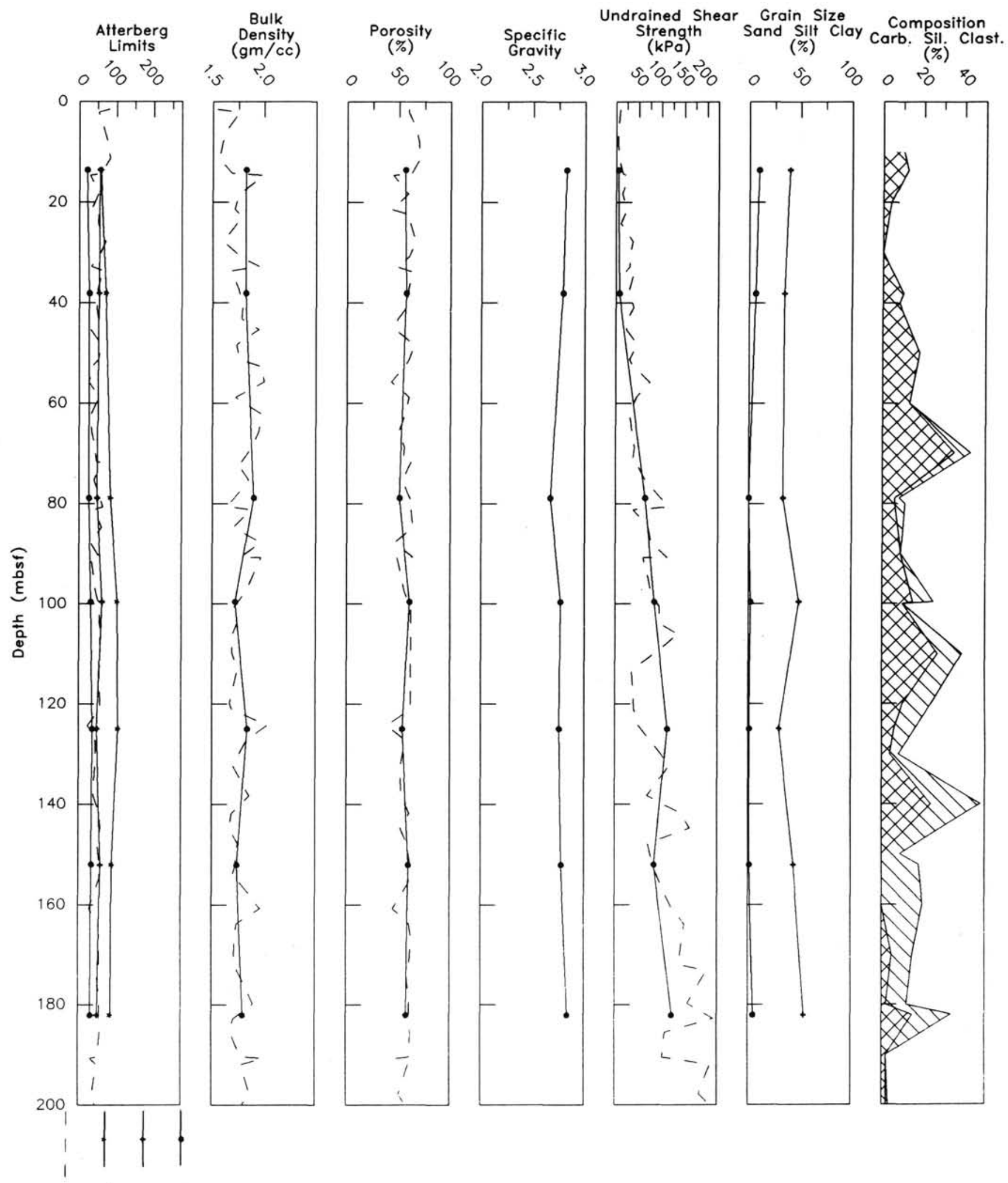

wn wl w wp

Figure 2. Site 644 geotechnical properties profiles. wp, w, wl, and wn are plastic limit, water content (consolidation samples), liquid limit, and water content (shipboard), respectively. Solid lines are trends of shore-based laboratory results. Dashed lines are shipboard data for Site 644. Grain-size and composition trends are cumulative percent. Composition is from smear-slide data plotted at $10-\mathrm{m}$ intervals and at consolidation sample locations. 

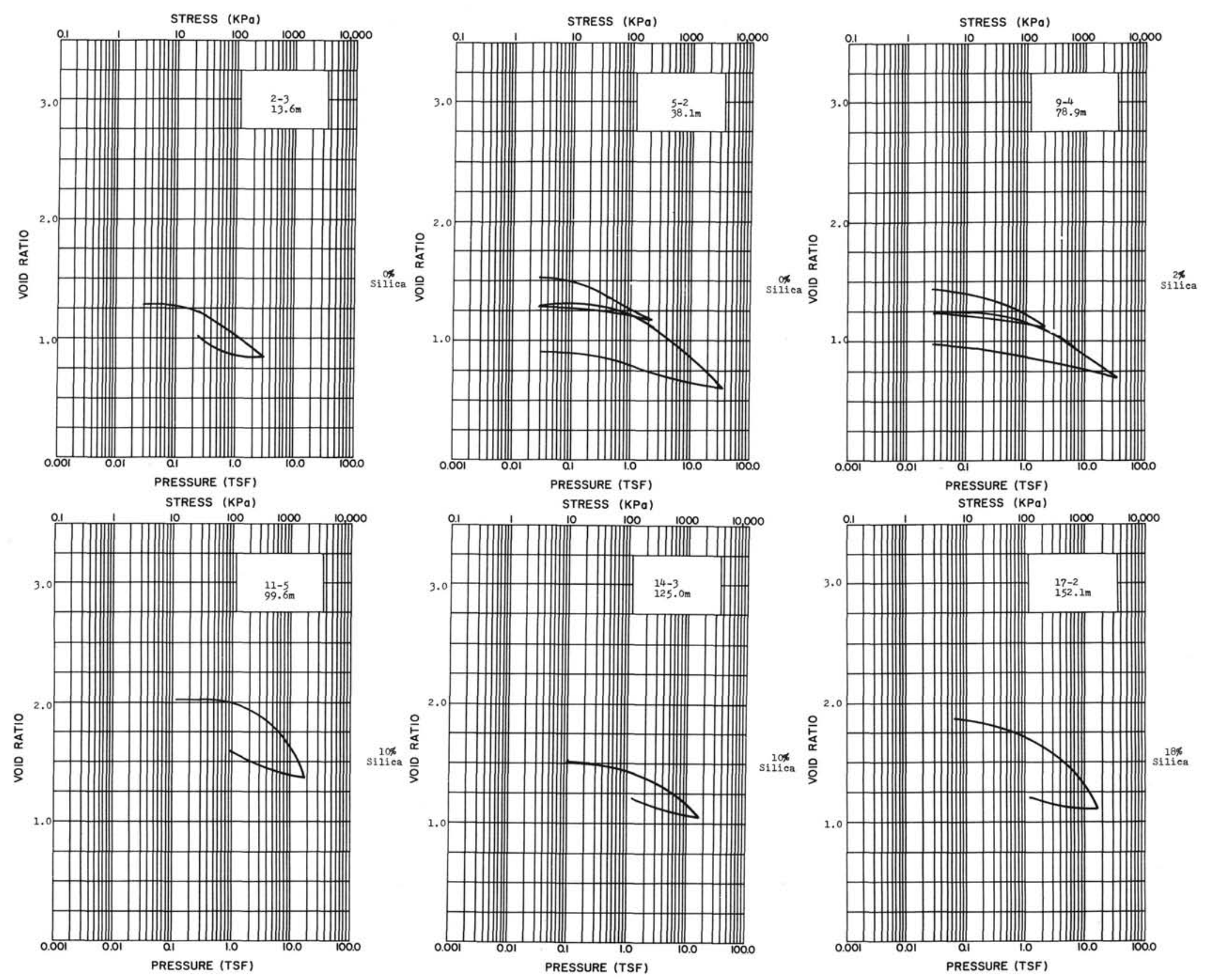

Figure 3. Consolidation test curves for Site 644 sediments. Sample depths are in meters below seafloor. Percent silica is from smear-slide data. 
Table 2. Geotechnical properties of Norwegian Sea sediments.

\begin{tabular}{|c|c|c|c|c|c|c|c|c|}
\hline $\begin{array}{c}\text { Core } \\
\text { section }\end{array}$ & $\begin{array}{l}\text { Depth } \\
\text { (mbsf) }\end{array}$ & $\begin{array}{l}\text { Compression } \\
\text { index, } C_{c}\end{array}$ & $\begin{array}{c}\text { Preconsolidation } \\
\text { pressure, } P_{c} \\
(\mathrm{kPa})\end{array}$ & $\begin{array}{c}\text { Effective } \\
\text { overburden } \\
\text { pressure, } \\
P_{o}(\mathrm{kPa})\end{array}$ & $\begin{array}{c}\text { Over } \\
\text { consolidation } \\
\text { ratio } \\
\left(P_{c} / P_{o}\right)\end{array}$ & $\begin{array}{l}\text { Observed } \\
\text { liquidity } \\
\text { index, } I_{l}\end{array}$ & $\begin{array}{l}\text { Predicted } \\
\text { liquidity } \\
\text { index, } I_{l n}\end{array}$ & $\begin{array}{c}\text { Biogenic } \\
\text { silica } \\
\text { ( } \% \text { from } \\
\text { smear slide) }\end{array}$ \\
\hline \multicolumn{9}{|c|}{ Site 642} \\
\hline $2-5$ & 12.2 & 3.85 & 40.9 & 85.5 & 0.48 & 0.78 & 0.48 & 0 \\
\hline $5-4$ & 35.3 & 0.49 & 30.3 & 247.5 & 0.12 & 0.60 & 0.38 & 0 \\
\hline $8-4$ & 62.8 & & & 440.3 & & & & 0 \\
\hline $11-4$ & 91.3 & 3.20 & 600.0 & 578.9 & 1.04 & 0.36 & 0.62 & 37 \\
\hline $17-3$ & 142.4 & 2.08 & 650.0 & 816.9 & 0.79 & 0.46 & 0.51 & 52 \\
\hline $20-5$ & 174.8 & 1.38 & 500.0 & 950.7 & 0.53 & 0.29 & 0.56 & 40 \\
\hline $23-4$ & 200.0 & 0.25 & 47.0 & 1053.1 & 0.01 & 0.30 & 0.51 & 58 \\
\hline \multicolumn{9}{|l|}{ Site 643} \\
\hline $2-4$ & 11.2 & 0.25 & 20.8 & 75.4 & 0.28 & 0.79 & 0.21 & 0 \\
\hline $5-5$ & 41.2 & 2.70 & 500.0 & 276.9 & 1.81 & 0.35 & 0.58 & 0 \\
\hline $8-5$ & 69.7 & 5.27 & 600.0 & 412.4 & 1.45 & 0.55 & 0.58 & 20 \\
\hline $11-5$ & 97.9 & 2.86 & 700.0 & 513.3 & 1.36 & 0.38 & 0.92 & 52 \\
\hline $14-5$ & 126.7 & 0.31 & 50.0 & 600.6 & 0.08 & 0.45 & 0.76 & 75 \\
\hline $18-2$ & 160.2 & 1.46 & 340.0 & 700.8 & 0.49 & 0.40 & 0.75 & 72 \\
\hline \multicolumn{9}{|l|}{ Site 644} \\
\hline $2-3$ & 13.6 & 0.53 & 45.0 & 94.1 & 0.48 & 0.92 & 0.41 & 0 \\
\hline $5-2$ & 38.1 & 0.86 & 50.0 & 263.6 & 0.19 & 0.58 & 0.40 & 0 \\
\hline $9-4$ & 78.9 & 0.43 & 60.0 & 576.7 & 0.10 & 0.39 & 0.36 & 2 \\
\hline $11-5$ & 99.6 & 1.20 & 210.0 & 733.3 & 0.29 & 0.43 & 0.38 & 10 \\
\hline $14-3$ & 125.0 & 0.50 & 290.0 & 921.4 & 0.32 & 0.18 & 0.35 & 10 \\
\hline $17-2$ & 152.1 & 0.90 & 210.0 & 1121.9 & 0.19 & 0.44 & 0.29 & 18 \\
\hline $20-3$ & 182.1 & 0.36 & 25.0 & 1344.4 & 0.02 & 0.34 & 0.26 & 19 \\
\hline
\end{tabular}

lidation decreases with depth. Below $125 \mathrm{~m}$ the trend once again reverts to one of increasing underconsolidation with depth.

Observed liquidity index is greater than predicted (Fig. 5), suggesting underconsolidation above 100 and below 140 mbsf. A trend of decreasing degree of underconsolidation to near normally consolidated, followed by possible overconsolidation, is observed between 40 and 140 mbsf. While these two measures of consolidation state indicate differing degrees of consolidation, both consistently indicate a decrease in the degree of underconsolidation over the same depth range. This interval between approximately 75 to 140 mbsf contains the highest abundance of silica found in the section at Site 644 (Fig. 2).

Undrained shear strength measurements suggest a normal trend of increasing strength with depth (Fig. 2). This agrees with the trend for Site 644 determined from the much larger number of measurements made aboard ship (Eldholm, Thiede, Taylor, et al., 1987).

\section{Site 642}

Seven samples were tested from Site 642, ranging in depth from 12 to 202 mbsf. The seaward location of Site 642 relative to 644 is reflected in the increased pelagic character of the sediments. Samples at this site are clays and muds (Table 1). Coarse clastics are generally less abundant while carbonate, silica, and clay have increased (Fig. 6). As at Site 644, there is little change in grain-size distribution with depth suggesting that differences in the vertical distribution of geotechnical properties, and differences between the two sites, result primarily from compositional changes. An abrupt change in composition occurs at about 60 mbsf. The overlying, predominantly coarse clastic and clay section changes to sediments with much lower sand and silt content and with larger amounts of silica and carbonate (Fig. 6). Biogenic silica is absent above $60 \mathrm{~m}$ but is a significant component below this depth.

The section above $60 \mathrm{mbsf}$ is characterized by relatively high bulk density and specific gravity along with lower porosity, water content, and Atterberg limits (Fig. 6). Unlike the trends in other properties, specific gravity does not change abruptly at 60 mbsf. This may be due to the high carbonate contents of samples at 91 and 142 mbsf.

The trends of increasing water content and porosity and decreasing bulk density with depth below 60 mbsf are contrary to what would be expected for sediments responding to vertical loading, i.e., undergoing dewatering and compaction, and appear to be correlated with generally increasing biogenic silica content downsection. As at Site 644 , the plasticity indices also increase in proportion to the amount of silica present. The proportionately greater plastic index at Site 642 appears to be a consequence of higher overall silica content compared to Site 644.

The $e-\log P^{\prime}$ curves for Site 642 samples (Fig. 7) display a greater range of initial void ratios and several show larger changes in void ratio during consolidation, i.e., undergo a greater consolidation during testing relative to Site 644 samples. These characteristics are a reflection of the more heterogeneous sediment compositions at this site. Curves tend to fall into two groups: Samples 104-642B-5H-4 at 35 mbsf and -642B-2H-5 at 12 mbsf are from the upper, clastic-rich portion of the section and are similar to the $e$-log- $P^{\prime}$ curves for Site 644 samples. They have low initial void ratios and small changes in void ratio during loading. Curves for the more deeply buried, siliceous and calcareous samples usually have high initial void ratios and undergo more consolidation during testing.

In general, more deeply buried samples have lower values of compression index (Fig. 8). This trend is probably a response to vertical changes in composition because $C_{c}$ would be expected to remain constant for sediments of the same composition provided the sediment matrix has not undergone incipient cementation.

Estimated in-situ coefficients of permeability for all samples at Site 642 are low $\left(10^{-7}\right.$ to $10^{-8} \mathrm{~cm} / \mathrm{s}$, Fig. 8). Calculated values are generally an order of magnitude lower than measured values but show the same trend with depth.

Both methods used to determine consolidation state indicate decreasing degrees of underconsolidation below about $40 \mathrm{mbsf}$ 


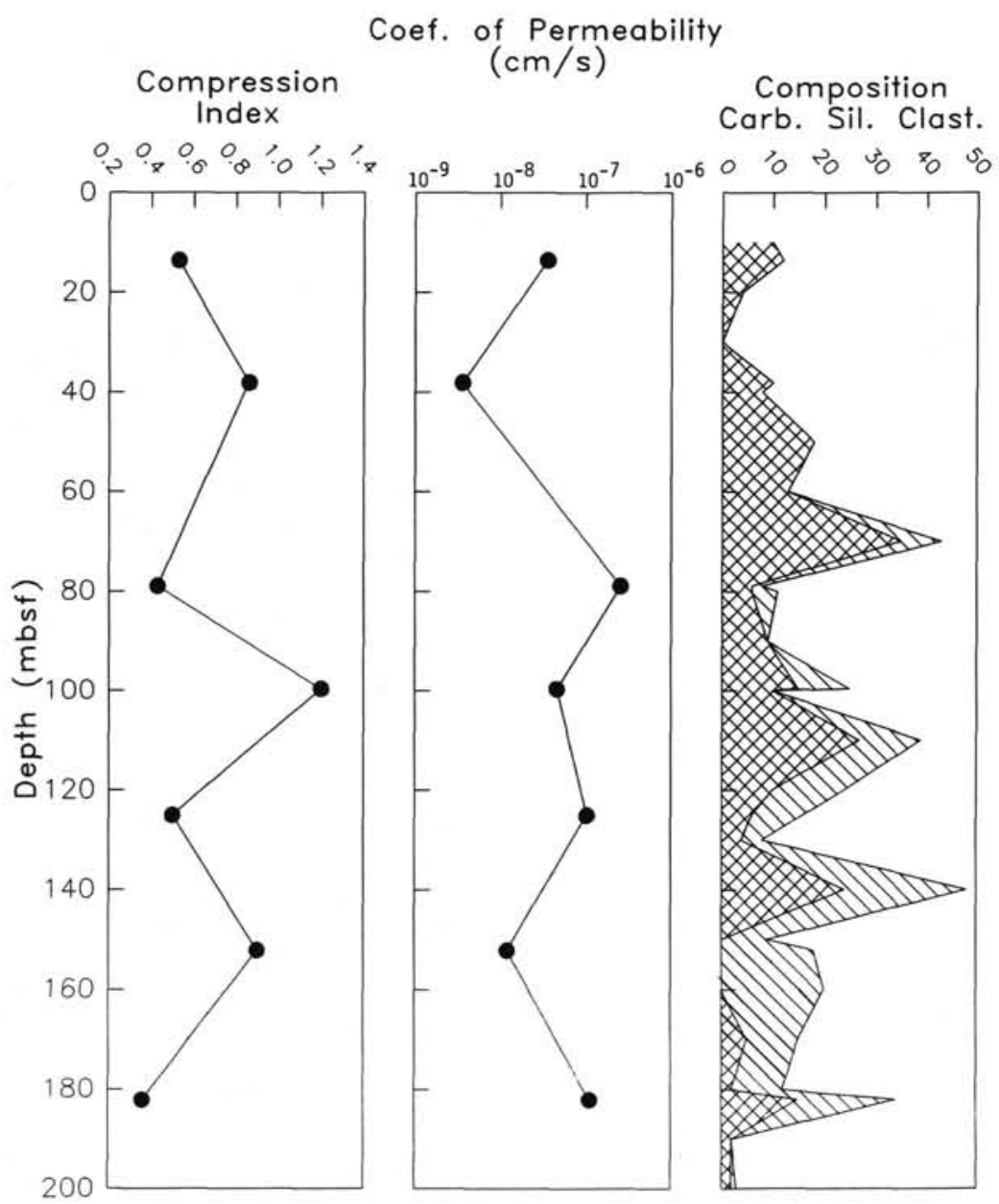

Figure 4. Profiles of compression index and in-situ coefficient of permeability ( $k$ at preconsolidation pressure) for Site 644 sediments. Composition is cumulative percent from smear-slide data plotted at $10-\mathrm{m}$ intervals.

and overconsolidation at 90 mbsf (Fig. 9). Sediments below this interval are underconsolidated according to pressure indices but appear normal to overconsolidated according to liquidity indices. This interval corresponds with waning abundance of biogenic silica above about 100 mbsf (Fig. 6).

Undrained shear strength increases with depth down to about 60 mbsf, where it abruptly decreases (Fig. 6). Below about 90 mbsf shear strengths increase with depth, although at a less rapid rate than in the upper portion of the section. These trends were also observed in the data collected aboard ship (Eldholm, Thiede, Taylor, et al., 1987).

\section{Site 643}

Site 643 is the seaward limit of the site transect across the Vøring Plateau (Fig. 1). The site, located in $2753 \mathrm{~m}$ water depth, has been the locus of primarily pelagic and hemipelagic sedimentation except for Pliocene-Pleistocene glacial input. Six samples were selected for consolidation tests from Site 643, ranging in depth from 11 to 160 mbsf. These samples are silts, muds, and clays (Table 1).

Grain-size distributions are similar to those of the two previous sites with the exception of the much higher silt content around $70 \mathrm{mbsf}$ and slightly higher percentages of sand and silt throughout the section (Fig. 10). This suggests that the vertical distribution of geotechnical properties, as at the two previous sites, is primarily the result of variations in composition.
The sedimentary section is similar to that of Site 642 ; an abrupt change in composition occurs at about $60 \mathrm{mbsf}$ from relatively high sand, silt, clay and carbonate content to sediment below this depth in which biogenic silica becomes the predominate constituent (Fig. 10). Carbonate is less abundant in the lower portion of the section than at Site 642. Other properties reflect these changes and, as at Site 642 , the anomalous trends of decreasing bulk density with depth and associated increases in water content and porosity are observed. Again, this anomalous trend is associated with the first occurrence of biogenic silica. Atterberg limits also increase with depth, especially below $60 \mathrm{mbsf}$ where samples have the largest values of plastic index observed along the Vøring Plateau transect. This high plastic index appears to be directly proportional to the increased abundance of silica relative to the previous sites. Shear strength increases with depth to $70 \mathrm{mbsf}$ and then shows a decreasing trend (Fig. 10).

The $e-\log P^{\prime}$ curves for Site 643 (Fig. 11) have the highest range of initial void ratios observed along the transect. As at Site 642 they fall into two groups: those from the shallower, more clastic, clay and carbonate portion of the sediment section above $70 \mathrm{mbsf}$ and those from the primarily siliceous section below. The former typically have relatively low initial void ratios and undergo relatively little consolidation during testing. The latter have the highest initial void ratios observed along the transect and exhibit the largest reductions in void ratio during con- 

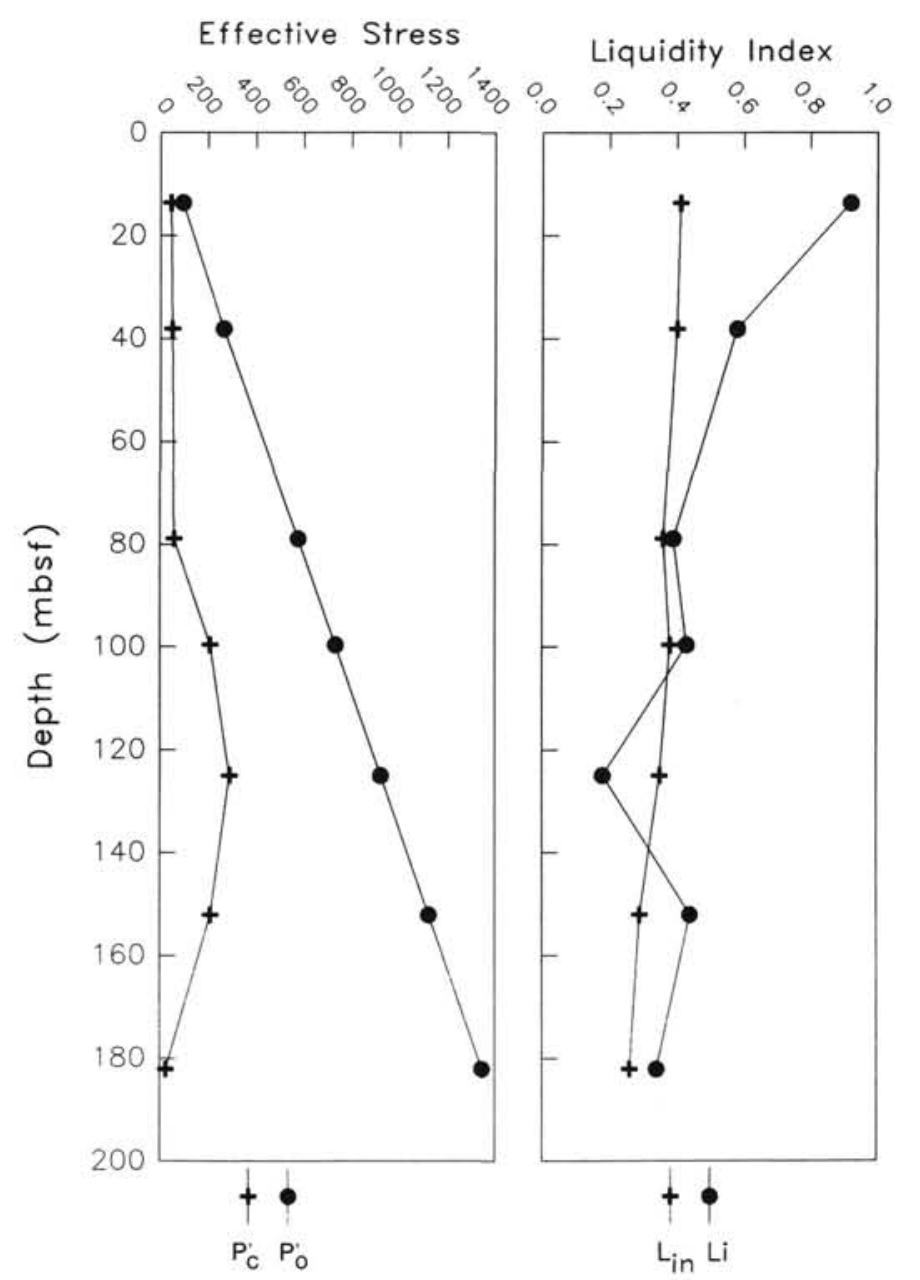

Figure 5. Profiles of preconsolidation pressure $\left(P^{\prime}{ }_{c}\right)$, effective overburden pressure $\left(P^{\prime}\right)$, measured liquidity index $\left(L_{i}\right)$, and predicted liquidity index $\left(L_{i n}\right)$ for Site 644 sediments.

solidation, with the exception of Section 104-643A-14H-5 at 127 mbsf.

Compression indices are variable and show no consistent relationship with depth (Fig. 12), suggesting that the variability is related to changes in composition. Calculated in-situ permeabilites are again significantly lower than measured values but exhibit similar trends and indicate higher permeabilities in the siliceous facies underlying less permeable, clastic and carbonate sediments (Fig. 12).

Indices of consolidation state indicate a decrease in the degree of underconsolidation with depth and overconsolidation around 40 mbsf (Fig. 13). Liquidity indices suggest overconsolidation to at least 160 mbsf whereas the relationship between effective overburden pressure and preconsolidation pressure indicate a return to underconsolidation below $100 \mathrm{mbsf}$. The inter$\mathrm{val}$ of overconsolidation corresponds to waning abundance of biogenic silica up section and a zone of high clay content (Fig. 10).

\section{DISCUSSION}

The range of values and trends of index properties (bulk density, porosity, and water content) for consolidation samples show no significant variation from values determined earlier on samples analyzed aboard ship and indicate little desiccation during shipment and storage. X-radiographs indicate no obvious mechanical disturbance prior to cutting and loading of samples for consolidation tests. Shore-based shear strength measurements are generally comparable to, but slightly lower than, shipboard values. The former were made with the vane rotated parallel to bedding while those on ship were taken with the vane rotated perpendicular to bedding. This suggests some slight anisotropy of shear strength in the two directions, variations resulting from differences in vane mechanisms, or sample disturbances induced during shipping and handling.

Among the factors often cited as controlling the distribution of geotechnical properties are lithology, texture, and overburden pressure (Bryant et al., 1981; Bennett and Nelsen, 1983; Taylor, 1984), environment and rate of deposition (Shephard et al., 1979; Shephard and Bryant, 1983) and postdepositional processes other than overburden pressure (Bennett and Nelsen, 1983). These factors will not be equally important within any given geological setting.

On the Vøring Plateau, grain-size distribution does not change significantly either vertically or laterally with the exception of local, coarse-grained deposits. Consequently, primary depositional texture, in so far as it is influenced by particle size, does not appear to have been an important factor in determining the distribution of geotechnical properties.

Samples in this study were obtained between subsurface depths of 10-200 mbsf. Typically, sediments undergo a significant volumetric reduction in response to overburden pressure in this range; however, this is not the case for sediments cored on the Vøring Plateau. The expected trends in index properties, i.e., decreasing porosity and water content and increasing bulk density, are not observed. At two sites, 642 and 643, observed index properties trends in the lower portions of these sections are the reverse of the expected trends. Shear strength normally increases in a linear fashion with depth in response to overburden pressure (Bryant et al., 1981). However, shear-strength profiles generated from shipboard samples (Eldholm, Thiede, Taylor, et al., 1987) and from this study for Sites 642 and 643 (Figs. 6 and 10) suggest inflections, and possible reversals, of shear-strength gradient with depth. Void ratio-effective stress curves generally show a decrease in the range of consolidation for more deeply buried samples (Bryant et al., 1981, and Taylor, 1984). Sites 642 and 643 exhibit the opposite trend (Figs. 7 and 11).

The lack of evidence for burial response and the correlation of index property values and trends, Atterberg limits, and $e$-log $P^{\prime}$ character with changes in composition, indicate that lithology and textural parameters other than grain size are among the most important factors controlling the distribution of geotechnical properties on the Vøring Plateau. Both lateral and vertical changes in sediment composition are present in the cores studied. The most significant variables are the amounts of clay and carbonate, and a trend of decreasing clastics and increasing biogenic silica with increasing distance from land and increasing age.

Variations in geotechnical properties of ODP Leg 104 core samples reflect these stratigraphic changes. The relatively high clastic-clay, variable carbonate, and low silica content of Site 644 and the upper portions of Sites 642 and 643 are characterized by relatively high bulk densities and specific gravities, and low Atterberg limits, porosities, permeabilities, and water contents. Consolidation samples from this facies have low initial void ratios and undergo relatively little consolidation during testing. These sediments are Pleistocene age and younger, and are the result of alternating periods of glacial and nonglacial conditions.

Vertical lithologic changes occur abruptly at the more seaward sites, proceeding from the more clastic facies above to a predominantly siliceous facies below. This same facies change occurs laterally, with silica increasing seaward, but is much more gradational (Figs. 2, 6, and 10). This transition is associated with abrupt decreases in bulk density and also with decreased 


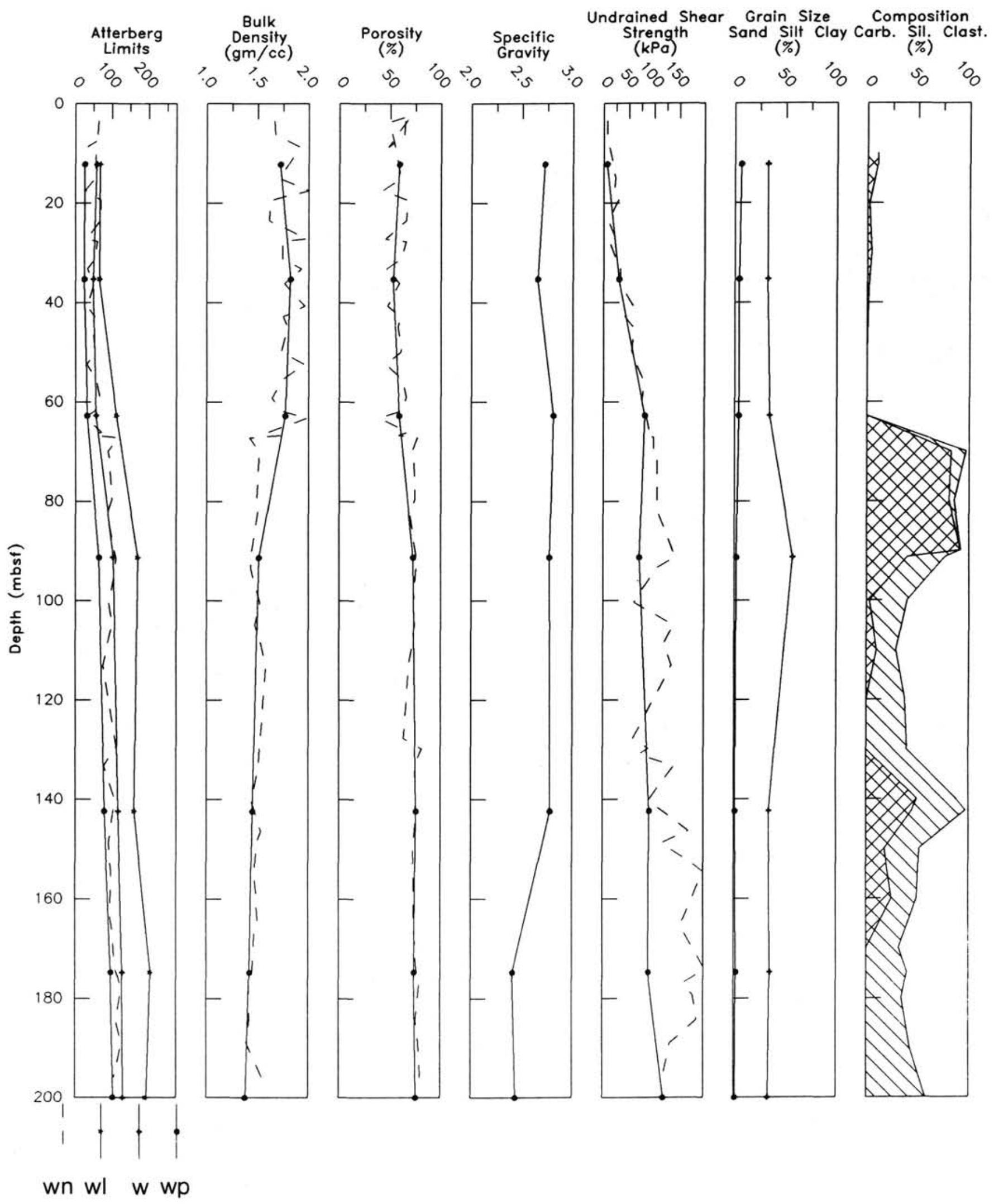

Figure 6. Site 642 geotechnical properties profiles. wp, w, wl, and wn are plastic limit, water content (consolidation samples), liquid limit, and water content (shipboard), respectively. Solid lines are trends of shore-based laboratory results. Dashed lines are shipboard data for Site 642 . Grain-size and composition trends are cumulative percent. Composition is from smear-slide data plotted at $10-\mathrm{m}$ intervals and at consolidation sample location. 

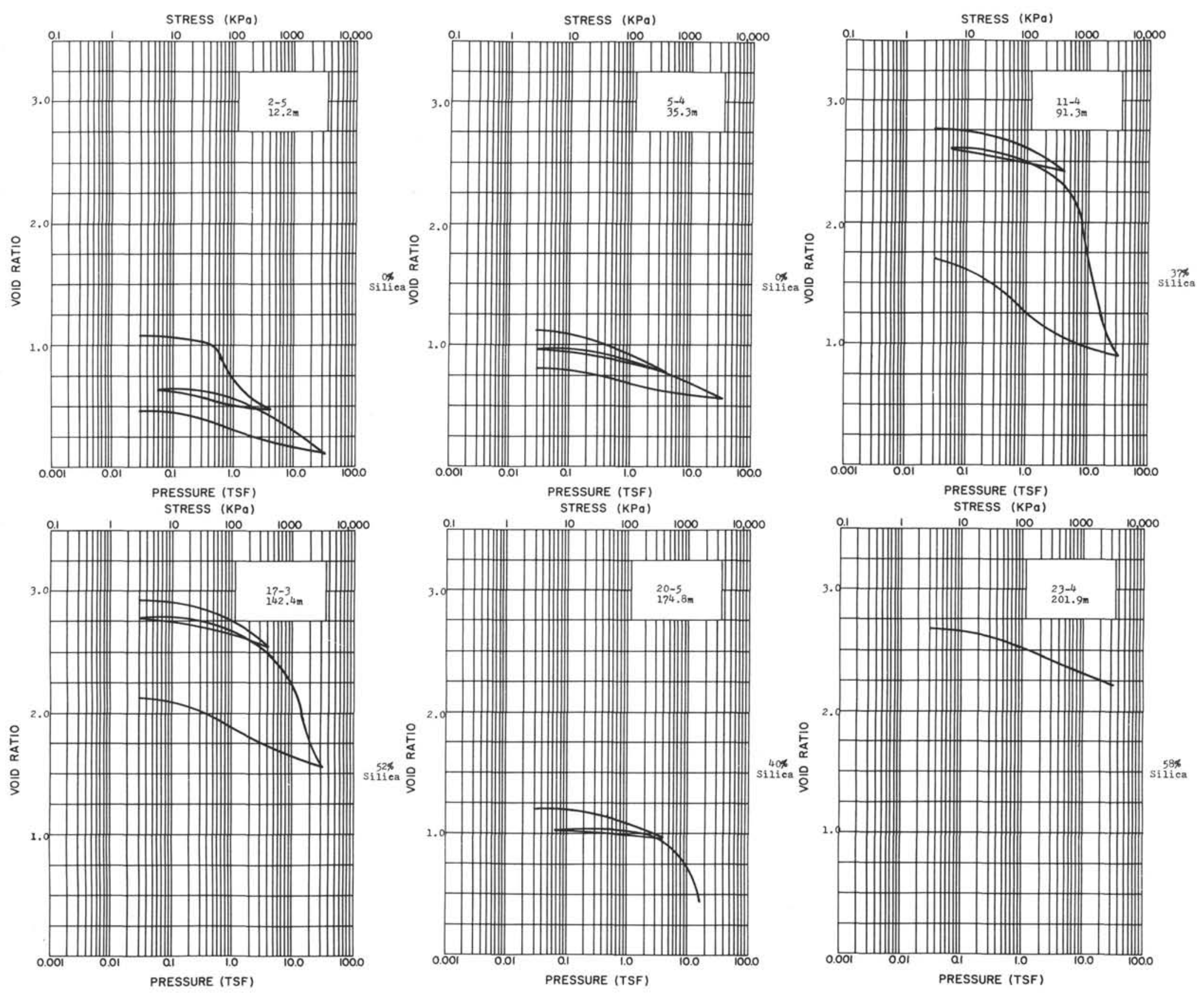

Figure 7. Consolidation test curves for Site 642 sediments. Sample depths are in meters below seafloor. Percent silica is from smear-slide data. 


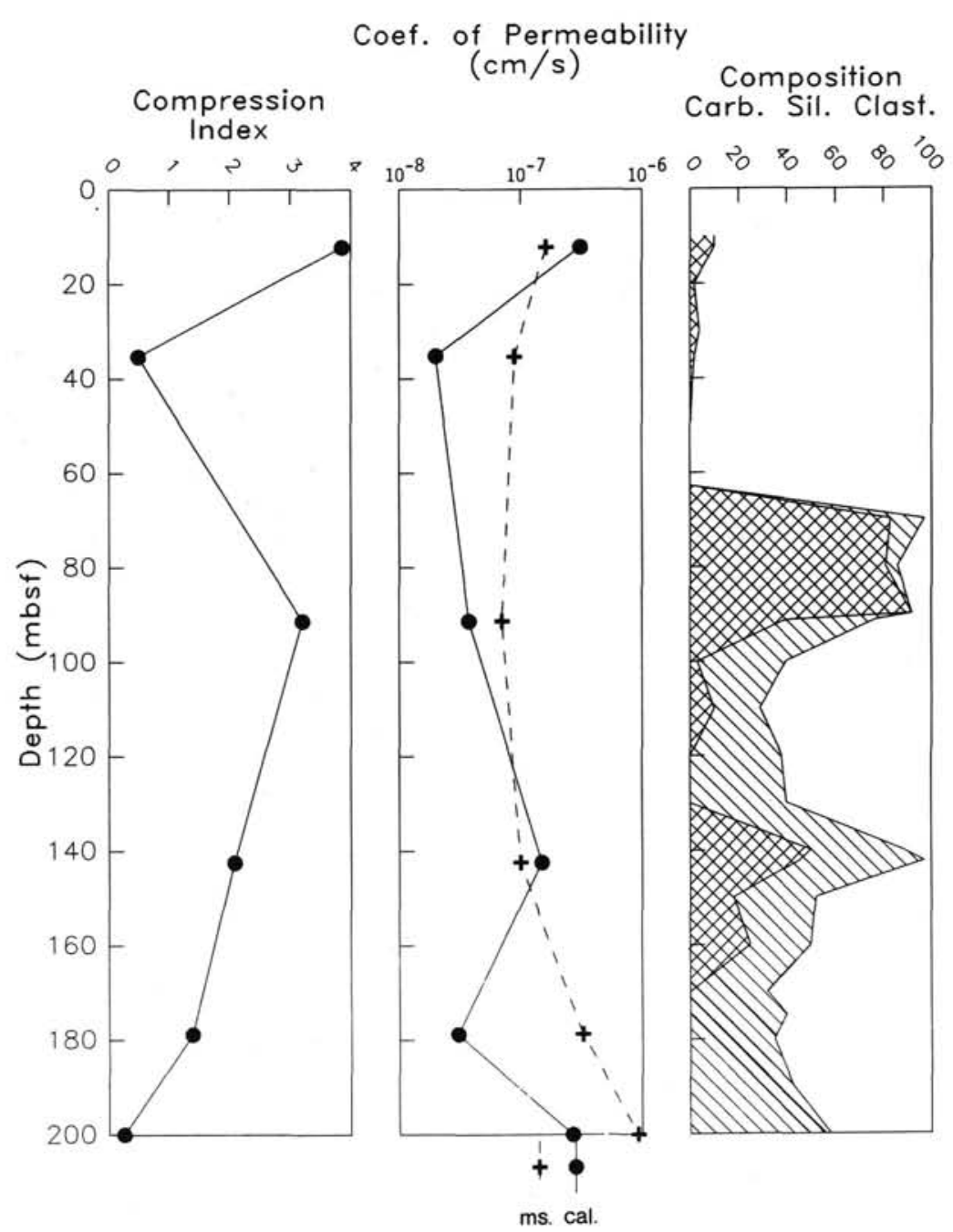

Figure 8. Profiles of compression index and in-situ coefficient of permeability ( $k$ at preconsolidation pressure) for Site 642 sediments. Solid line is $k$ calculated from consolidation tests. Broken line is $k$ measured by falling head tests. Composition is cumulative $\%$ from smear-slide data plotted at $10-\mathrm{m}$ intervals and at consolidation sample locations.

shear-strength gradients. Porosity, water content, and Atterberg limits increase abruptly in the siliceous sections. There are only minor changes in index properties in the upper facies. In the lower, more siliceous sediments, lateral changes are most evident in the change in Atterberg limit values along the transect; values increase seaward. This change is associated with a progressive increase in water contents and liquid limits that can be correlated vertically at each site and laterally along the transect, with increasing abundance of biogenic silica (Fig. 14). These properties show a slight negative correlation with clay content (Fig. 14).

Permeability and $e-\log P^{\prime}$ curves reflect these same facies changes. Plots of $e-\log P^{\prime}$ curves for each site (Figs. 3, 7, and 11) show a gradual increase in the range of initial void ratios and in the change in void ratio (during consolidation tests) seaward, but also show a sample-depth association that reflects the abrupt vertical lithologic changes at Sites 642 and 643 .

Figure 15 is a plot of calculated coefficients of permeability vs. change in void ratio for all samples after each load increment during consolidation tests. The trends are typical of finegrained marine sediments in that they show large changes in $k$ with relatively small changes in void ratio (Bryant et al., 1974).
The trends suggest that for a given change in $k$, a larger change in void ratio, i.e., more consolidation, is required as silica content increases from Site 644 through Site 643. Coefficient of permeability values for each site tend to plot as three separate tracts which can be correlated with relatively low silica content along the lower tract to relatively high silica content along the upper tract (Fig. 15).

Calculated permeabilities, although exhibiting similar trends with depth, are consistently lower than values obtained from falling head tests (Figs. 8 and 12). Calculated values of $k$ were used for Fig. 15 because results from a falling head test are not believed to be accurate at very low values (Bryant et al., 1975). One possible source of error in a falling head test occurs when the back pressure is not sufficient to ensure complete saturation. An air phase would impede flow of water, thereby reducing the permeability. This is not the case here as observed values are higher, not lower, than calculated values. Taylor (1984) suggested that the difference between calculated and direct $k$ values may be the result of seepage-induced consolidation produced by relatively high hydraulic gradients associated with the falling head test. This would produce faster dewatering of the sample and, consequently, anomalously high permeabilities. It seems 

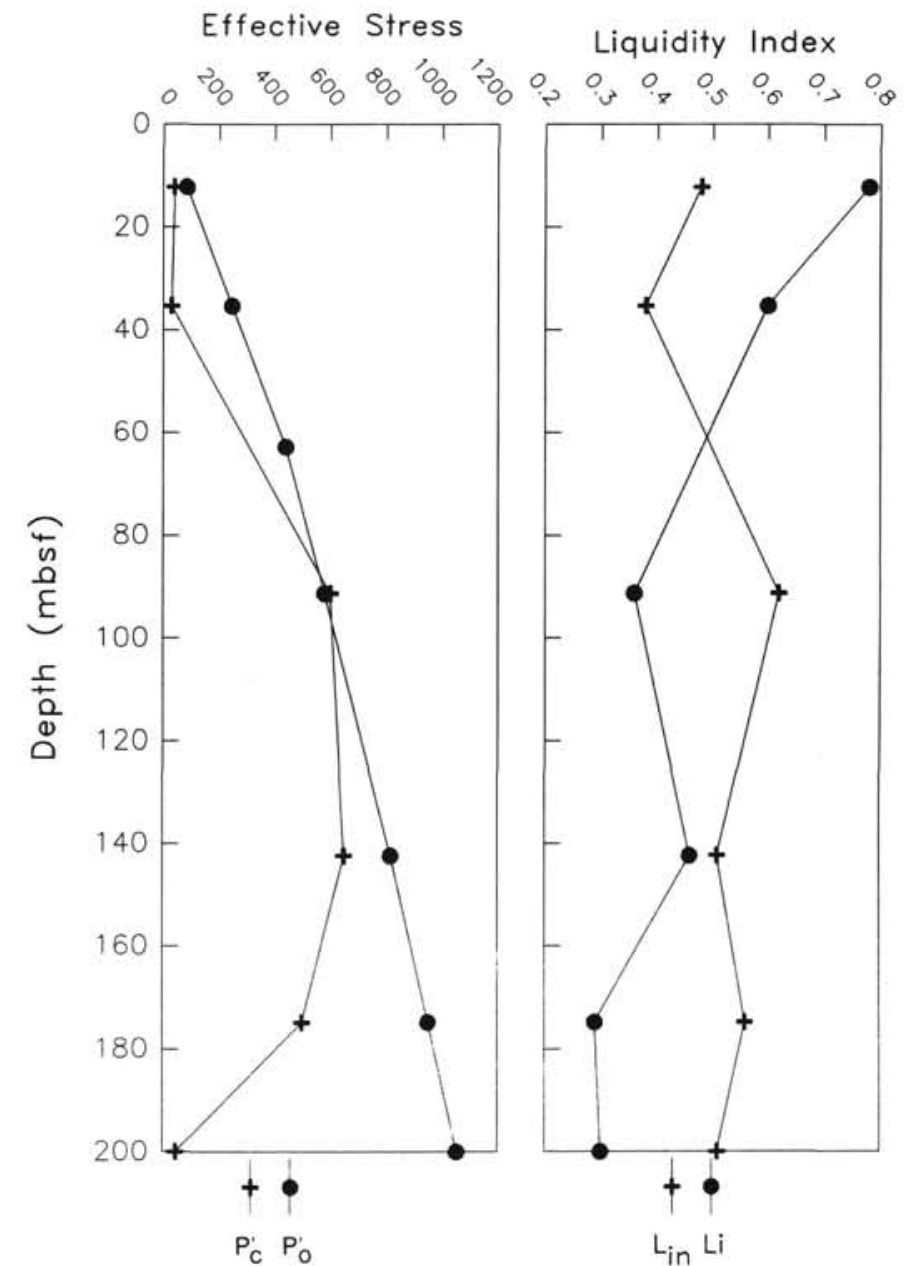

Figure 9. Profiles of preconsolidation pressure $\left(P^{\prime}{ }_{c}\right)$, effective overburden pressure $\left(P^{\prime}{ }_{0}\right)$, measured liquidity index $\left(L_{i}\right)$, and predicted liquidity index $\left(L_{i n}\right)$ for Site 642 sediments.

reasonable to assume that this effect would become more pronounced in more permeable sediments. Figures 8 and 12 suggest this: calculated and measured $k$ values have the same trend, but measured values are higher. If these higher, direct values are due to seepage consolidation which, in turn, is more pronounced in more permeable sediments, the difference between calculated and direct results should increase as $k$ increases. This is the general trend at Site 642 (Fig. 8) and is very obvious at Site 643 (Fig. 12). The enhanced effect of seepage consolidation appears to be much greater at Site 643 relative to Site 642 , in consequence of the greater abundance of relatively high permeability sediment, i.e., biogenic silica at Site 643 (Figs. 8 and 12).

A systematic change in consolidation state occurs along the Vøring Plateau transect generally within the 50 to $125 \mathrm{mbsf}$ depth interval. Both indices of consolidation state indicate a trend of decreasing degree of underconsolidation to overconsolidation within this interval (Figs. 5, 9, and 13). Pressure indices also indicate a return to underconsolidation below this interval. However, liquidity indices suggest continued overconsolidation at greater depths. The approximately 50 to $100 \mathrm{mbsf}$ interval is correlated at all three sites with a zone of abrupt vertical change in composition associated with the occurrence of biogenic silica. It is probable that two factors have operated to produce overconsolidation in this particular portion of the section: reduced sedimentation rate and the primary depositional texture of siliceous sediments.

Marine sediments often show increasing underconsolidation with depth (Kolb and Kaufman, 1967; Bryant et al., 1975;
Shephard et al., 1979; Taylor, 1984). This lack of consolidation is probably a result of rapid sediment accumulation relative to the rate of dewatering as a consequence of the generally very low permeabilities of fine-grained marine sediments (Bryant et al., 1974). Conversely, overconsolidation can result from slow sedimentation rates which allow more time for greater drainage and may be associated with a sedimentary hiatus. Erosion of overburden followed by renewed sediment accumulation tends to produce overconsolidation in the older sediments (Bryant et al., 1981). Evidence for lower sedimentation rates during deposition of the overconsolidated interval on the Vøring Plateau is the decreasing biogenic silica and increasing clay content upsection. This evidence suggests waning productivity of biogenic sediment, probably a result of the onset of glacial conditions (Eldholm, Thiede, Taylor, et al., 1987). It is within this same 50 to $100 \mathrm{mbsf}$ interval that the degree of overconsolidation increases seaward along the transect (Figs. 5, 9, and 13).

The effect of slow sedimentation rate on the consolidation character of sediments in the $50-100$ mbsf interval was probably facilitated by the texture of the underlying siliceous sediment, which contains porous constituents, diatoms and silicoflagellates. Siliceous tests are probably responsible for the high void ratios and water contents and the relatively high degree of consolidation during testing associated with samples from this facies. Higher initial void ratios are also associated with higher permeabilities (Bryant et al., 1974, and Fig. 15). Relatively high permeability along with a slow rate of deposition would permit rapid dewatering, facilitating the development of apparent overconsolidation in surficial sediments (Shephard et al., 1979). Below about $125 \mathrm{~m}$, there is a return to the trend of increasing underconsolidation with depth. This is not reflected by liquidity indices however, which appear to break down as indicators of consolidation state in siliceous sediments. The siliceous section as a whole (except for the 50 to $125 \mathrm{mbsf}$ interval), is probably underconsolidated. The combination of the accumulation of low density, high porosity sediments with higher accumulation rates, followed by deposition of an overlying relatively lower permeability sediment results in a perfect scenario for underconsolidation.

Slumping at Site 643 (Eldholm, Thiede, Taylor, et al., 1987) may have occurred in association with the overconsolidated interval. Slope instability at this site may be related to biogenic silica associated with this interval or to the change in consolidation state across the interval. The effect of silica in the section creates a relatively less dense, water-enriched layer underlying more dense sediment. Undrained shear strength, which is a function of void ratio and water content (Silva, 1974), continues to increase with depth through this interval although at a less rapid rate (Fig. 6) and may actually decrease with depth within some intervals (Figs. 6 and 10). Siliceous sediments generally have lower shear strengths compared to carbonates and clastics (Bryant et al., 1981) and as with other sediments, strength decreases as porosity and water content increase (Bryant et al., 1981). Consequently, the siliceous portion of the section may represent a plane of weakness along which slope accumulations tend to fail.

The primary factors influencing the geotechnical stratigraphy of the Vøring Plateau appear to have been lithologic composition and possibly sedimentation rate. These in turn have varied in response to passive margin tectonics, i.e., seafloor spreading (Eldholm and Windisch, 1974), the proximity of continental sediment sources, basin morphology, and modification of paleoceanographic circulation associated with glacial conditions (Thiede et al., 1986). The relative influence of these factors has varied in space and over time. Consequently, the values and ranges of geotechnical properties of sediments, and the factors controlling their distribution, are expected to have varied likewise, even within the same tectonic setting. The resulting 


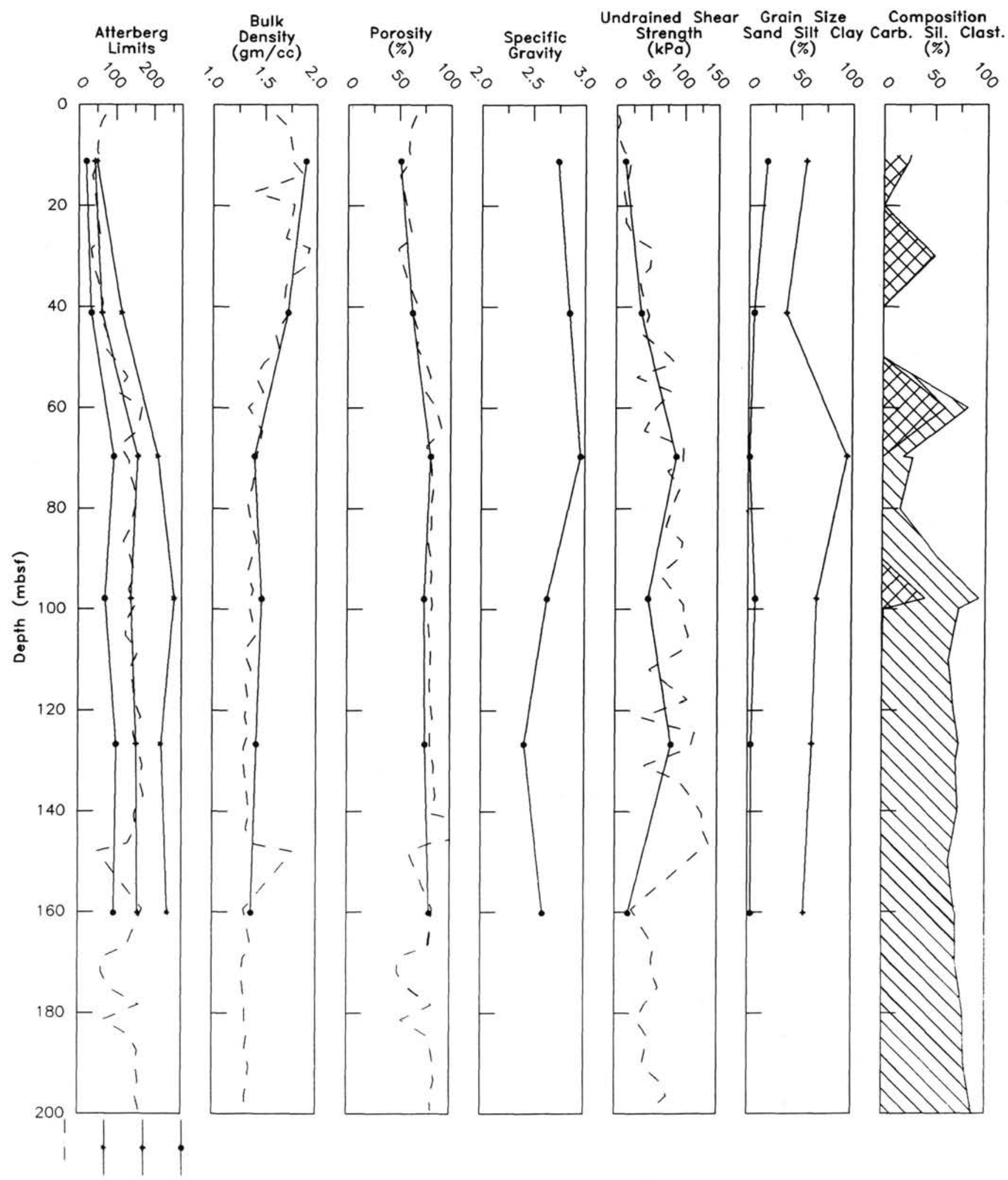

wn wl w wp

Figure 10. Site 643 geotechnical properties profiles. wp, w, wl, and wn are plastic limit, water content (consolidation samples), liquid limit, and water content (shipboard), respectively. Solid lines are trends of shore-based laboratory results. Dashed lines are shipboard data for Site 643 . Grain-size and composition trends are cumulative percent. Composition is from smear-slide data plotted at 10-m intervals and at consolidation sample locations. 

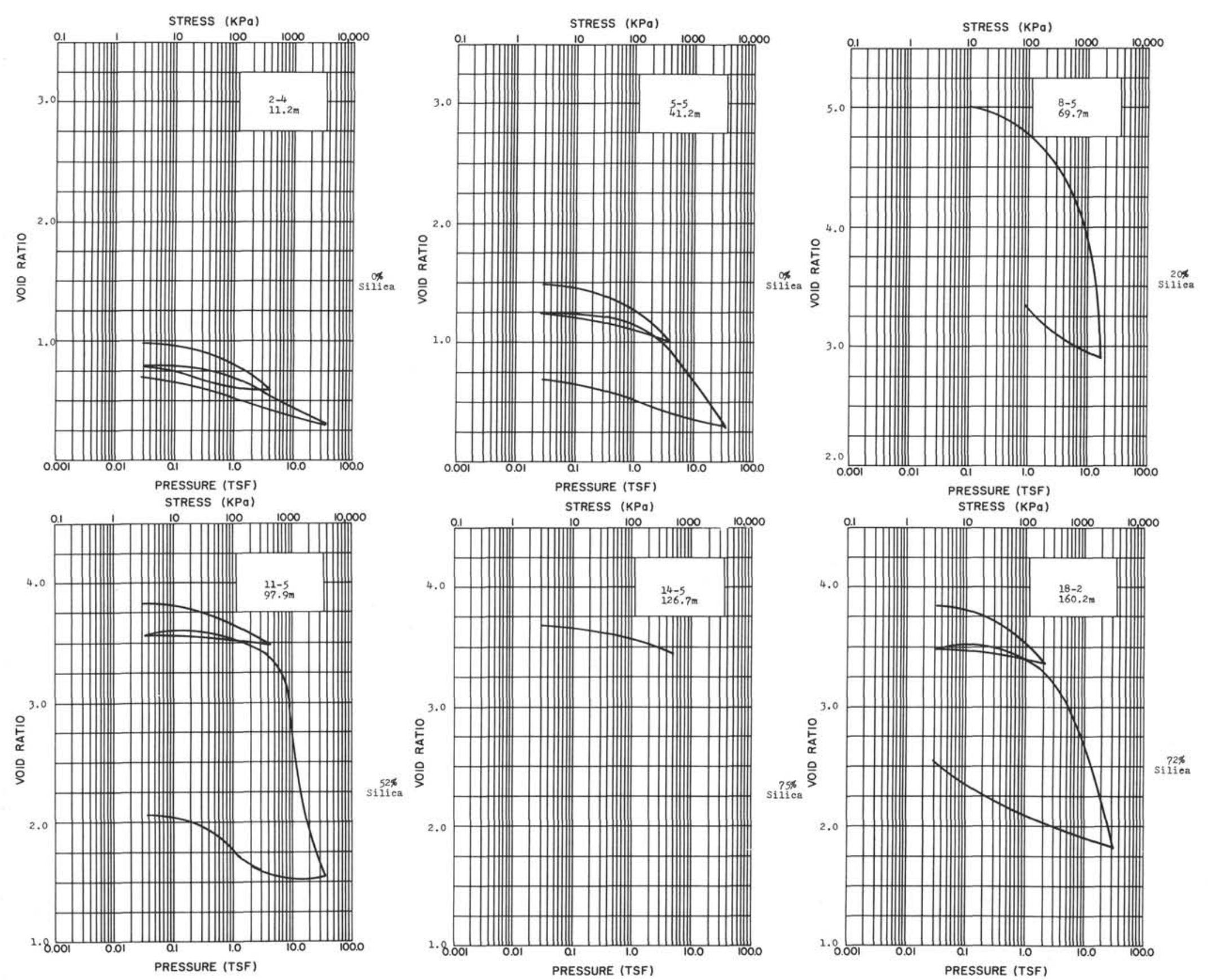

Figure 11. Consolidation test curves for Site 643 sediments. Sample depths are in meters below seafloor. Silica is from smear-slide data. 


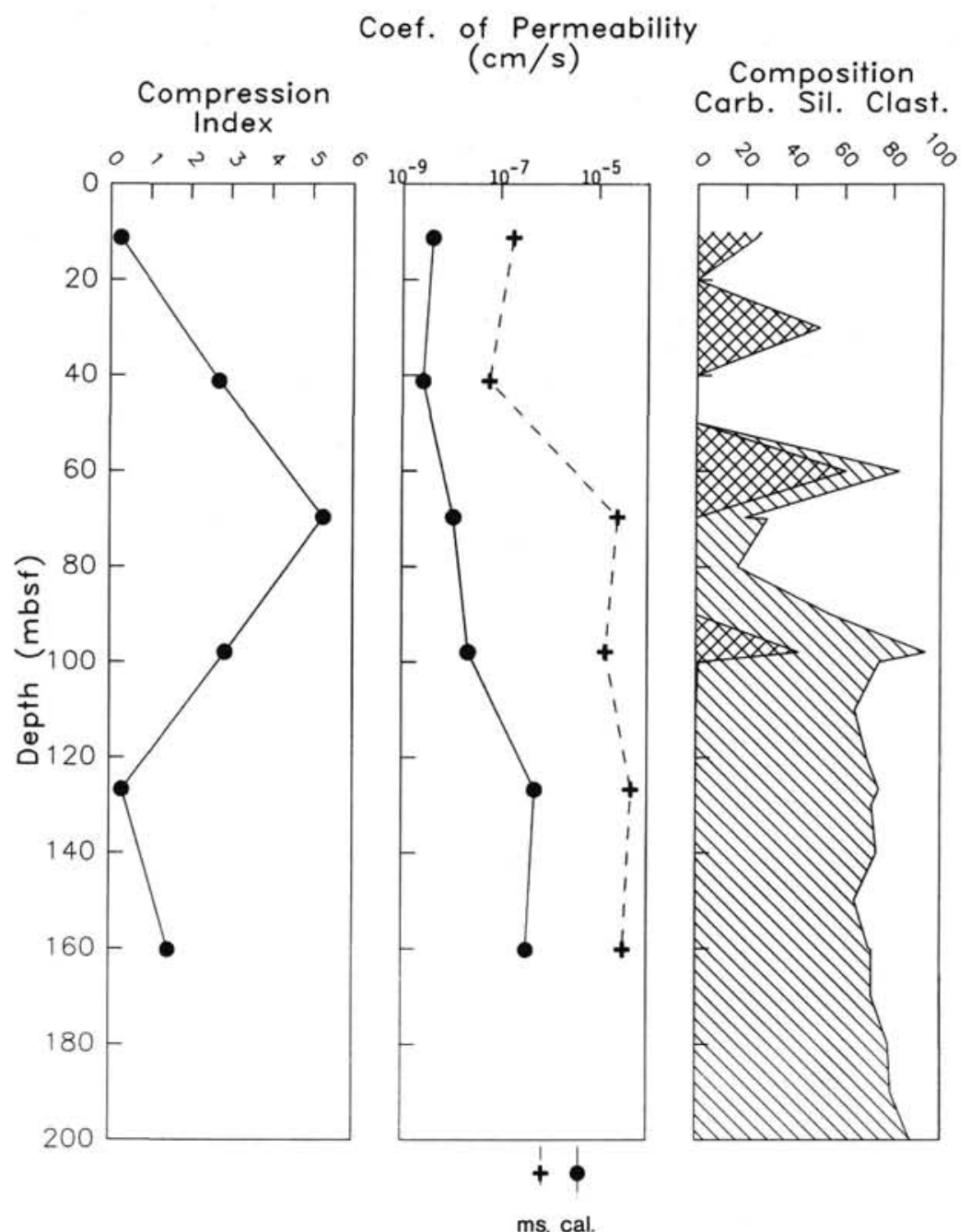

Figure 12. Profiles of compression index and in-situ coefficient of permeability ( $k$ at preconsolidation pressure) for Site 643 sediments. Solid line is $k$ calculated from consolidation tests. Broken line is $k$ measured from falling head tests. Composition is cumulative percent from smear-slide data plotted at 10 -m intervals and at location of consolidation samples.

geotechnical stratigraphy implies different potentials for fluid movement, cementation, subsidence, developement of densityvelocity interfacies, and slope stability within, and between, various geologic settings. Analysis of these properties and processes requires an understanding of the geotechnical properties associated with specific types of sediments, distribution of these properties, and the factors controlling their distribution.

\section{CONCLUSIONS}

1. Composition and possibly sedimentation rates have been the most important factors influencing the geotechnical stratigraphy in this area. Vertical and lateral changes in geotechnical properties are associated with changes in the composition of the sediments, in particular, biogenic silica content.

2. Grain size and overburden pressure appear to have had little significant influence on geotechnical properties of Vøring Plateau sediments.

3. Physical and geotechnical properties of the siliceous sediments in this high-latitude environment create stratigraphically distinct units with specific and varying geotechnical, acoustic, and slope stability characteristics.

\section{REFERENCES}

Bennett, R. H., and Nelsen, T. A., 1983. Seafloor characteristics and dynamics affecting geotechnical properties at shelfbreaks: Soc. Econ. Paleontol. Mineral. Spec. Publ., 23:333-355.

Bryant, W. R., Deflache, A. P., and Trabant, P. K., 1974. Consolidation of marine clays and carbonates. In Inderbitzen, A. L. (Ed.), Deep Sea Sediments: Physical and Mechanical Properties, Vol. 2: New York (Plenum).

Bryant, W. R., et al., 1975. Permeability of unconsolidated and consolidated marine sediments, Gulf of Mexico. Mar. Geotechnol., 1:1-14.

Bryant, W. R., Bennett, R. H., and Katherman, C. E., 1981. Shear strength, consolidation, porosity and permeability of ocean sediments. In Emiliani, C. (Ed.), The Sea, Vol. 7, Oceanic Lithosphere: New York (John Wiley \& Sons), 1555-1616.

Casagrande, A., 1936. The determination of the preconsolidation load and its practical significance: Proc. Int. Conf. 1st, Soil Mechanics and Foundation Eng., 3:60-64.

Eldholm, O., Thiede, J., Taylor, E., et al., 1987. Proc. ODP, Init. Repts., 104: College Station, TX (Ocean Drilling Program).

Eldholm, O., and Windisch, C., 1974. Sediment distribution in the Norwegian-Greenland Sea. Geol. Soc. Am. Bull., 85:1661-1676.

Folk, R. L., 1974. Petrology of Sedimentary Rocks: Austin (Hemphill Pub. Co.). 
Helwick, S. J., Jr., 1977. Engineering properties of shallow sediments in West Delta and South Pass outer continental shelf lease areas, offshore Louisiana [M. Sc. Thesis]. Texas A\&M Univ., College Station.

Kolb, C. C., and Kaufman, R. I., 1967. Prodelta clays of southwest Louisana. In A. F. Richards (Ed.), Marine Geotechnique: Chicago (Univ. of Illinois Press), 3-21.

Lambe, T. W., 1951. Soil Testing for Engineers: New York (John Wiley \& Sons).

McClelland, B., 1967. The progress of consolidation in delta front and prodelta clays of the Mississippi River. In A. F. Richards (Ed.), $M a$ rine Geotechnique: Chicago (Univ. of Illinois Press), 22-40.

Shephard, L. E., Bryant, W. R., and Dunlap, W. A., 1979. Geotechnical properties and their relation to geologic processes in South Pass outer continental shelf lease area, Blocks 28, 47 and 48, offshore South Louisiana. Tech. Rep. 79-5-T, Texas A\&M Univ., Dept. of Oceanography, College Station.
Shephard, L. E., and Bryant, W. R., 1983. Geotechnical properties of lower trench-inner slope sediments. Tectonophysics, 99:279-312.

Silva, A. J., 1974. Marine geomechanics: overview and projections. In A. L. Inderbitzen (Ed.), Deep Sea Sediments: New York (Plenum Press), 45-76.

Taylor, E., 1984. Oceanic sedimentation and geotechnical stratigraphy: hemipelagic carbonates and red clays [Ph.D dissertation]. Texas A\&M Univ., College Station.

Thiede, J., et al., 1986. Patterns of Cenozoic sedimentation in the Norwegian-Greenland Sea. Mar. Geol., 69:323-352.

Date of initial receipt: 2 March 1987

Date of acceptance: 3 October 1988

Ms 104B-145

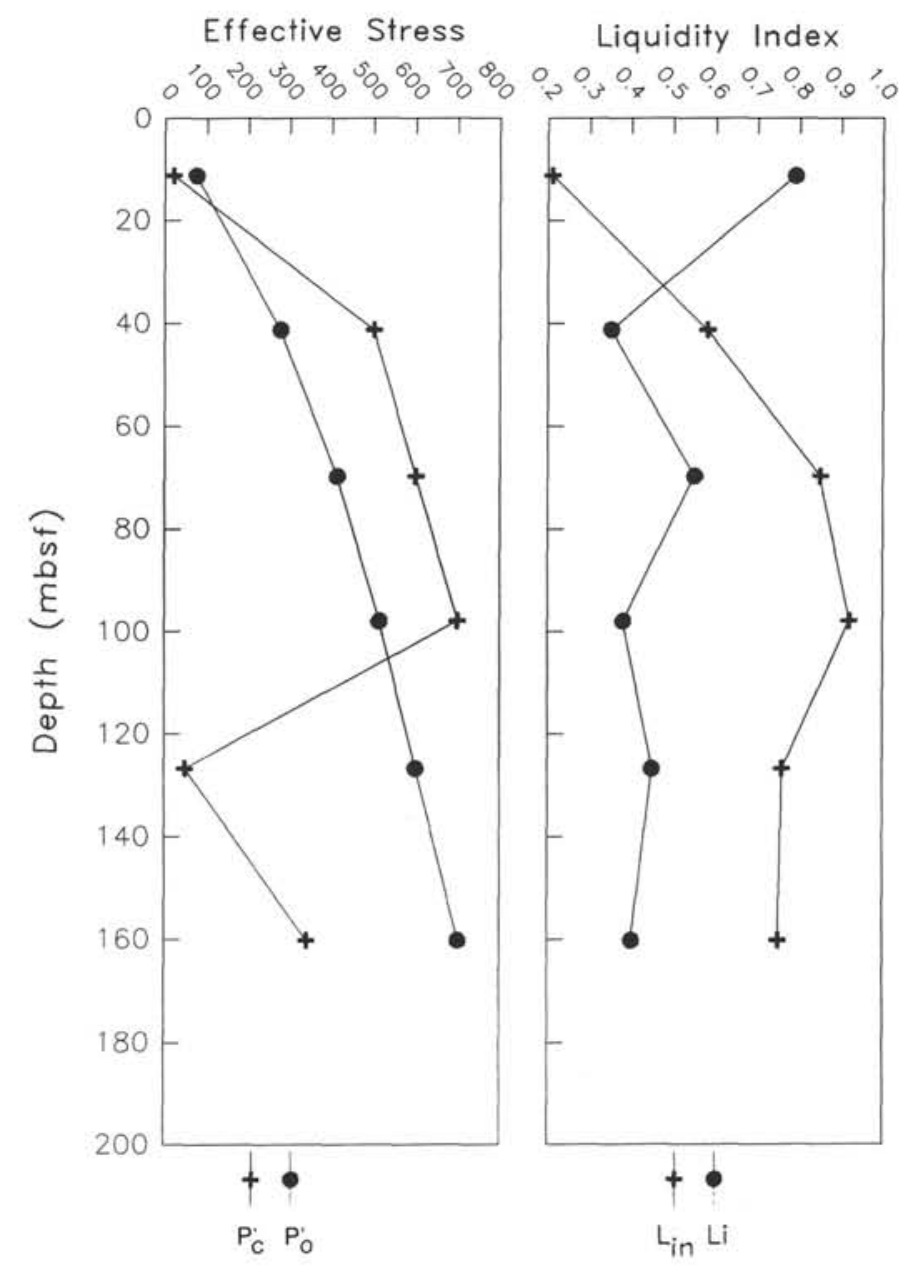

Figure 13. Profiles of preconsolidation pressure $\left(P^{\prime}\right)$, effective overburden pressure $\left(P^{\prime}{ }_{0}\right)$, measured liquidity index $(L i)$, and predicted liquidity index $\left(L_{\text {in }}\right)$ for Site 643 sediments. 


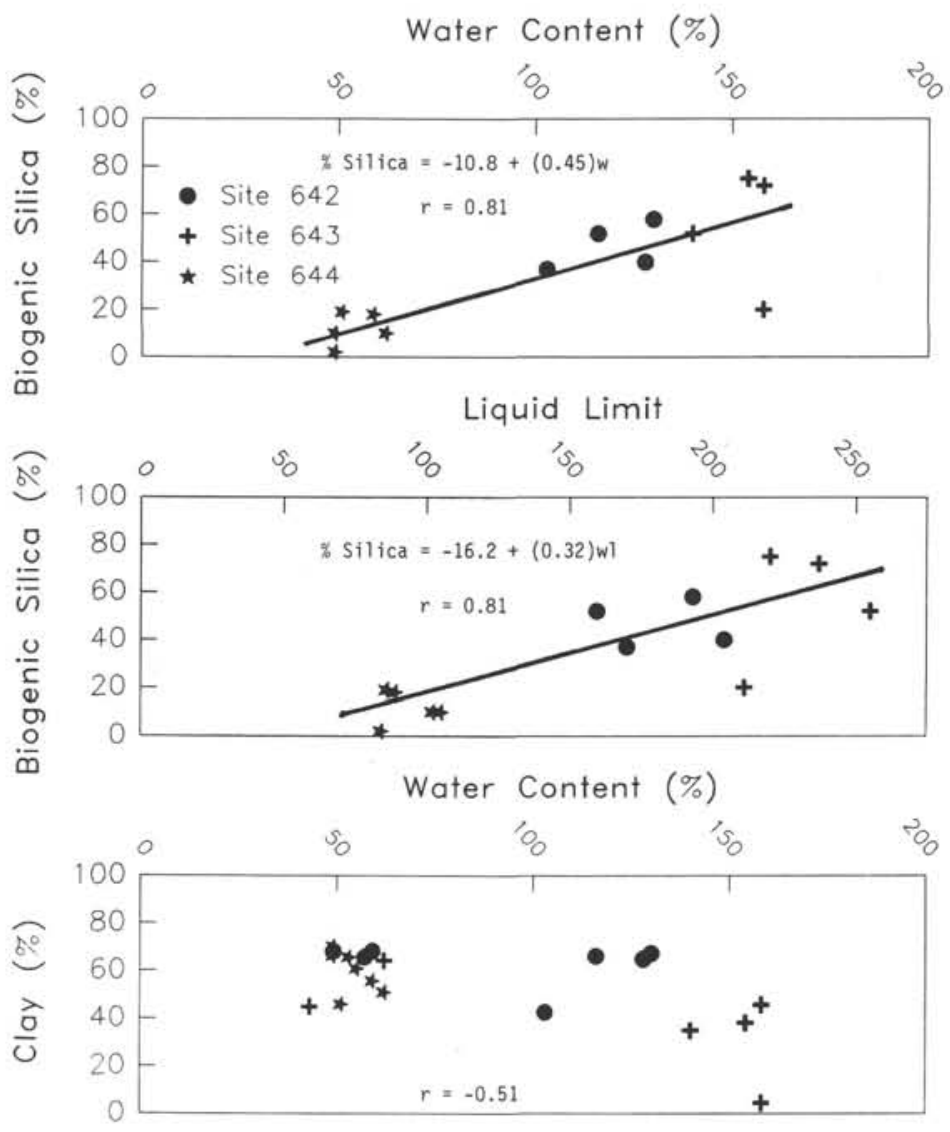

Figure 14. Relationship between percent silica, water content, and liquid limit, and between water and clay content for samples containing biogenic silica. Percent silica is from smear-slide data. Percent clay is from sieve analysis. Correlation coefficient $(r)$ is from linear regression analysis. 
A. PITTENGER, E. TAYLOR, W. BRYANT

$$
\begin{gathered}
\text { Coefficient of Permeability } \\
(\mathrm{cm} / \mathrm{s})
\end{gathered}
$$

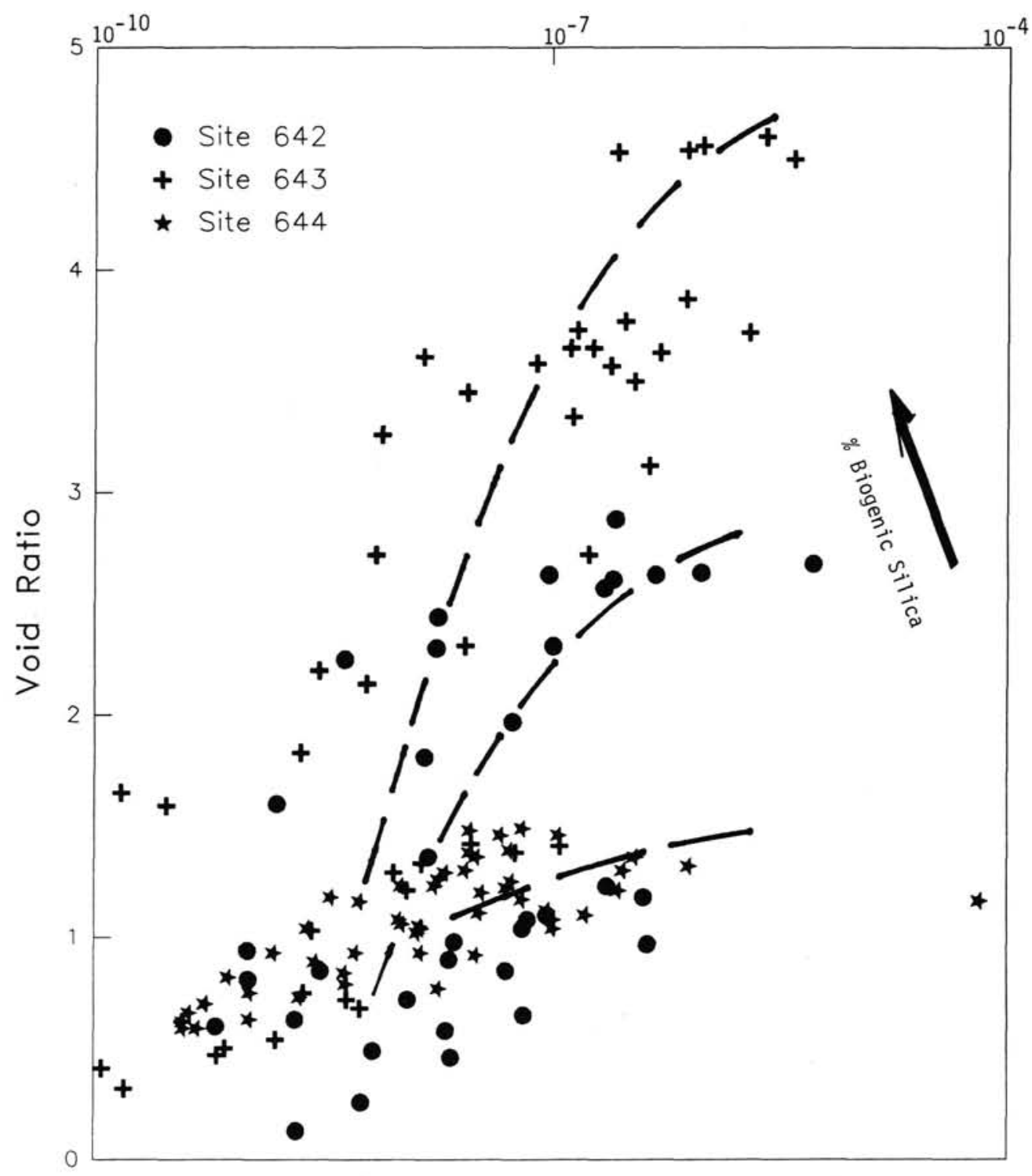

Figure 15. Relationship between permeability, void ratio, and biogenic silica from consolidation test samples. Data points represent calculated permeabilities after each load increment for all samples tested. Dashed lines are apparent trends for each site. 